\title{
Introduction
}

\section{Medical Case Histories as Genre: New Approaches}

Monika Class

The articles presented here set out the conceptual significance of case histories for the field of medical humanities and the history of medicine. The main objective of the collection is a critical inquiry into the similarities and differences among specific series of case histories in order to recover patterns and practices in texts and communicative acts about human health at different historical stages from the Renaissance until the late nineteenth century. In doing so, these articles pertain to a question raised in the 2013 spring issue of Literature and Medicine: "what does literature and medicine mean, and to whom? . . . What sort of conjunction does the 'and' really embody?"1 Like a go-between, the "and" in "Literature and Medicine" enables communication between the fields while it simultaneously suggests that the convergence of the distant groups is impossible. The history of case histories is a viable alternative to disciplinary contradistinction, offering ample room for genuine encounter and even giving us glimpses of past indivisibility.

The articles collected here continue work started in a 1992 special issue of Literature and Medicine that helped to stimulate a resurgence of interest in medical case histories. The present contributions, occasioned by the workshop on "Medical Case Histories as Genre" that took place at King's College London's Centre for the Medical Humanities and Health at Guy's Hospital in July 2013, embrace prose texts, medical history, literary theory, and philosophy of science. The essays avoid a single conceptualization of "medical case histories," eschewing a rigid trans-historical or ideal template exerting control over its various textual manifestations. ${ }^{2}$ None of these articles is interested in the "generic" as an antonym to "specific"; indeed, the cluster refrains from generalizations and seeks instead the meaning which is inherent in the Latin root 
"gen" (to beget, to be born, to come into being) that links "generic" with "generate" and "engender." 3 In this regard, the present contributions deviate from the special issue of 1992. Editors Joanne Trautmann Banks and Anne Hunsaker Hawkins then equipped readers with an understanding of the "standard form (with variations, of course) that has served medicine for decades," consisting of "a statement of the chief complaint, . . . the history of the present illness, past medical history, review of systems, family history, and social history, and end[ing] with the results of the physical examination and laboratory tests." ${ }^{4}$ The present collection does not pose their question "what is a medical case history?" Instead, these contributions deal with different epochs in the history of medical record taking, and discuss evolving, changing, or decaying features of medical case histories. The cluster supports the notion put forward in Gianna Pomata's article in this issue: case narratives, as the well-known Hippocratic Epidemics suggests, have existed in "embryonic" variations and since the Renaissance in full-fledged case collections and thus over a longer time (and as part of a larger number of different cultures) than commonly assumed; indeed, Pomata draws attention to the fact that medical case histories were certainly there prior to the end of the eighteenth century when written records became fully instrumental in "the professional institutionalization of medicine." ${ }^{5}$ Examining several episodes in the history of medical observations, ranging from antiquity to the nineteenth century, these articles all find case histories to be dynamic rather than stable structures. ${ }^{6}$

\section{Genre as Multidisciplinary Method}

Some might say that "no concept is more fundamental to literary study than genre." ${ }^{7}$ But our use of the term "genre" does not proffer a lesson in literary studies for historians and sociologists of medicine or vice versa. ${ }^{8}$ Such an approach might indicate rivalry, competition, and disciplinary boundaries in ways that Wolf Lepenies's Between Literature and Science has outlined. ${ }^{9}$ In the spirit of Immanuel Kant's Conflict of the Faculties (Streit der Fakultäten), Lepenies conceived of sociology as a third culture that erupted from the clash of literature and science, revealing the fundamental role of competition over academic reputation in the constitution of academic disciplines. This sense of disciplinary contest has played a part in the ongoing consolidation of the medical humanities as a field. In his 1981 article on the state 
of affairs of literature and medicine, George Rousseau gauged the development of the field against that of literature and science, noting that the "irony of this contrast . . . [was] that medicine surely ha[d] far more than science to offer literature and vice versa." 10 Without denying the productive implication of competition or the need for historical differentiation here, the present articles examine case histories as an alternative to disciplinary antagonism. Rather, the study of case histories enhances our understanding of the elusive meaning of the "and" in "Literature and Medicine," for case histories are and were a feature of many disciplines, including medicine, ethics, theology, law, anthropology, sociology, economics, and literature.

Similarly, twentieth- and twenty-first-century studies of genre combine a wide range of disciplines. In the twentieth century, the early work of the Bakhtin school did much "to connect genre to discourse and to pragmatics." 11 Drawing on Mikhail Bakhtin's concept of "speech genres,"12 Tzvetan Todorov proclaimed in Genres in Discourse: "there is not an abyss between literature and what is not literature[;]. . . literary genres originate, quite simply, in human discourse." 13 Todorov's work constitutes one of the many connections of Russian Formalism with the movement that came to be known as structuralism. Thinkers spearheaded by Marx, Levi-Strauss, Barthes, Foucault, and Bourdieu expanded the inquiry into patterns of texts, genres, languages, kinsystems, and so on into a range of methodologies for certain strands in philosophy, history, anthropology, sociology, and the philosophy of science. ${ }^{14}$ Ian Hacking, for instance, notes that "the work of [Thomas] Kuhn's final years can be said to be engaged in the logical syntax of the language of science." 15 The present uses of the term "genre" draw on this far-reaching legacy of structuralist and formalist approaches. At the same time, the contributors deliberately refrain from drawing a line, or taking sides, between structuralism and poststructuralism as if the pairing designated an inevitable choice between continuity, "discrete" units, "perfect" and "mystified" structures in the interest of "knowledge" and "truth" on the one hand and discontinuity, "messy interactions," and "misfiring events" in the interest of relativism on the other hand. ${ }^{16}$ Rather, these articles unpack the contradictory nature of emerging or decaying structures during various stages in the history of recorded medical observations, independent of such obsolete labels as "poststructuralism" in the twenty-first century.

The common take on "genre" in this joint publication revolves around the simple view that form is content. This includes morphological concepts of genre, such as Franco Moretti's Graphs, Maps, Trees, which 
likens the development of textual forms to biological evolution, as well as structural conceptions of genre. ${ }^{17}$ Regarding the latter, Nicolas Pethes notes that some scholars have drawn on Niklas Luhmann's systems theory in order to reach a structural understanding of genre. ${ }^{18}$ The basic idea is that texts are shaped by certain expectations that professional communities of writers and readers (medical, literary, etc.) gain from previous experience with similar texts. In consequence, every "new" text either confirms or deviates from these expectations. The articles here trace such confirmations and departures in the production and reception processes of cases. Similarly, continuities and discontinuities are salient, which brings us to an important point of contradistinction to Michel Foucault's take on medical observation and case writing.

\section{New Trends}

The work here builds partly on a growing trend in the study of medical history led by Gianna Pomata and John Harley Warner. ${ }^{19}$ It examines the ways in which continuities and discontinuities in the patterns of medical writing produce meaning and knowledge. Though a highly influential modern medical style of reasoning, case histories are not just verifiable or falsifiable references to the world outside the text. $^{20}$ They also convey performative elements that consist in bringing a state of affairs into existence. ${ }^{21}$ This idea finds expression in the writings of late eighteenth-century physician Marcus Herz, who noted that medical case histories are a matter of conscience and philanthropy because they "write experience into the world" ("Erfahrungen in die Welt hineinschreiben"). ${ }^{22}$ While the present contributors agree to disagree on the importance of the work of Foucault, none of their contributions concurs with Foucault's post-1968 position insofar as they do not express an interest in the operation of language and text formats that is consistently founded on the rejection of certain schools of thought. Foucault's History of Sexuality; Discipline and Punish; and Birth of the Clinic all argue against "humanism and the privileging of subjectivity; [against] hermeneutics/historicism and the privileging of understanding; [against] dialectics and the privileging of teleology, [and against] psychoanalysis and its privileging of a primal lack." ${ }^{23}$ Given that the present articles jointly engage with the foreign country that the past has become (to borrow from L. P. Hartley's The Go-Between), they take account of the above-mentioned schools of thought from sympathetic as well as critical vantage points, without privileging discontinuities over continuities, institutions over individuals, or contingency over teleology. 


\section{Continuity in the Histories of Medical and Legal Cases}

With regard to such continuities, three of the present articles discuss the relation between legal and medical case collections. As stated in the beginning of The Archaeology of Knowledge, Foucault focused on recovering discontinuities of concepts and practices that included medical cases, and this bias appears to have affected his analysis of the medical case. In Discipline and Punish, he detected an alleged rupture between medical cases and casuistry or jurisprudence: "The examination, surrounded by all its documentary techniques, makes each individual a 'case': a case which at one and the same time constitutes an object for a branch of knowledge and a hold for a branch of power. The case is no longer, as in casuistry or jurisprudence, a set of circumstances, defining an act and capable of modifying the application of the rule." 24 In Foucault's view, only legal cases can function as exemplars; only they are capable of modifying the norm, whereas medical cases are limited to the instantiation of pathologies. ${ }^{25}$ The articles by Pomata, Pethes, and Class help to revise this Foucauldian assumption and recover lasting connections between legal and medical practices in record taking.

\section{Some Basic Functions of Cases}

In the growing body of scholarship about medical case histories, three interrelated functions of cases have become key. ${ }^{26}$ First of these is the propaedeutic function of cases, of collections collated either outside of, or as a preparation for, a scientific model. As such, cases usually represent a kind of empirical foundation for the induction of knowledge and theories. The second function is bound up with the relation of the particular and the universal, with the particular serving as an example of the universal (instantiation). This type designates perhaps the most common understanding of the function of medical case histories. The Lexikon für Literatur und Medizin (Dictionary for Literature and Medicine), for instance, defines the medical case narrative as the particular manifestation of a customary disease. ${ }^{27}$ However, a third type pertains to those situations in which the particular and the universal do not coalesce, that is, when the case does not match up with a customary disease. This kind of case points to a singularity that may trigger modification of a system or a new hypothesis. ${ }^{28}$ Bound up with all three functions is the distinction between example versus exemplar, the mere subordination of a particular under a universal 
(example) versus a very best and particularly instructive example (exemplar). ${ }^{29}$ This distinction has played an important part in functional analyses of the case. ${ }^{30}$

\section{A Short Outline}

The present joint collection continues these discussions. It does so, however, without adhering to these types of functions as separate or rigid categories. Instead, the following articles are dedicated to the exploration of the inexhaustible diversity of medical case narratives and aim mainly to open up new questions. In "The Medical Case Narrative: Distant Reading of an Epistemic Genre," Pomata distinguishes between literary and epistemic genres. She argues that we should consider the medical case history as an epistemic genre, that is, a genre directly related to cognitive practices. Adopting Franco Moretti's evolutionary notion of genres, she calls for a long-term approach to the history of the case narrative in pre-modern cultures, highlighting in particular its connection with two other epistemic genres, the commentary and the medical recipe. Building on Pomata's "epistemic genre," Nicolas Pethes argues that case histories are more than just another genre. As inherently cross-disciplinary, he suggests, case histories work against the idea of "genre" as generalizing typologies. Focusing on German literature between 1750 and 1850, Pethes challenges established views regarding the relationship between literary case narratives and the semantics of individuality. Zooming in on a particularly significant figure for late eighteenth-century medical humanities, Monika Class reconsiders the relation of Karl Philipp Moritz's notion of aesthetic autonomy and his extensive collection of psychological case narratives in the Magazine for Empirical Psychology (1783-1793), contending that Moritz's appeal to consider observations of people as ends in themselves, and not as means to a new science project, played a crucial role in his conception of the aesthetic notion of "uselessness."

Moritz's observations on people's way of walking also feature in next article. Brian Hurwitz shows how clinical and urban observations contribute to the case descriptions of James Parkinson's Essay on the Shaking Palsy (1817). Hurwitz elucidates the way two observational fields and descriptions from existing classificatory schemata are fused together in the compound narrative of the malady in the Essay, which enabled Parkinson to depict a long and complicated trajectory of involuntary movements as a single disease. Despite the lack of an 
etiological account and without secure clinico-pathological correlations, or a definitive treatment, Parkinson made the disorders of trembling, posture, and gait cohere narratively, embedding his description of a new disease profile in a deeply affecting, sentimental style.

Analyzing rhetorical strategies, Meegan Kennedy examines the complex convergence of affecting symptomatology and cultural symbolism in descriptions of heart disorders during the Victorian era. Like Hurwitz, Kennedy recovers the affective dimension of medical writing, referring to a wide range of nineteenth-century cardiologists including William Stokes, John Williams, Robert Semple, and Arthur Samson. Kennedy argues that the unique nature of cardiac suffering causes Victorian physicians' writing on heart disease to turn to a romantic discourse, especially the sensational, sentimental, or sympathetic language describing the "distress" of both patient and physician. All of the present articles endeavor to enhance our understanding of the question of how such short prose formats as medical case histories managed (and manage) to negotiate the gulf between the often uncontrollable conditions of human life and our desire to cure and be cured, to care and be cared for, and to know and make sense.

\section{NOTES}

1. Belling, "Preface," vii. In the same spirit, Ludmilla Jordanova's review article "And?"discusses the nature of the "and" in "art and science" / art and medicine."

2. See Frow, Genre, 23.

3. Bruno, Kant's Concept of Genius, 9.

4. Banks and Hawkins, "Editors' column," vii.

5. Epstein, "Historiography," 23.

6. "The perception that literary genres are dynamic rather than static-that they change and 'evolve' across time-is the single most important factor separating modern from earlier genre theory" (Duff, Modern Genre Theory, 232). See also Fowler, Kinds of Literature, 170.

7. Harpham, "Genre," 1635.

8. See Turner, "Lessons," 578.

9. Lepenies speaks of literature's "assault on sociology" in the fight over "adequate reproduction of the "prose of everyday circumstances," Between Literature and Science, 14.

10. Rousseau, "Literature and Medicine," 406. Rousseau revised this position in his 2011 essay "Medicine" (Routledge Companion to Literature and Science).

11. Reynolds, "Review," 275. The seminal Bakhtin/Medvedev book, The Formal Method in Literary Scholarship, first published in Russian in 1928, was tellingly subtitled A Critical Introduction to Sociological Poetics.

12. See Frow, Genre, 29-30.

13. Todorov, Genres in Discourse, 26. $13,22$.

14. See Turner, "Lessons from Literature," 580-81; Duff, Modern Genre Theory, 
15. Hacking, introduction to Structure of Scientific Revolutions, xxxiii.

16. During, Foucault and Literature, 17.

17. Moretti argues that "'temporary structures' is also a good definition for-genres: morphological arrangements that last in time, but always only for some time. Janus-like creatures, with one face turned to history and the other to form" (Graphs, Maps, Trees, 14). For a further morphological conception of genres, see Ryan, "On the Why, What, and How of Generic Taxonomy."

18. See Pethes's article in this cluster, and Voßkamp, "Gattungen als Literarisch-Soziale Institutionen." Genres are "recurrent patterns of language use [that] help to constitute the substance of cultural life . . . a conventional category of discourse based on large-scale typification of rhetorical action" (Miller, "Genre as Social Action," 163).

19. Gianna Pomata has published several seminal articles on "epistemic genres." See Pomata, "Sharing Cases"; "Observation Rising"; "Epistemic Genres." John Harley Warner currently works on the research projects "Vital Signs: Image, Identity, and the Aesthetic Grounding of Modern Medicine" and a study of the transformation of the hospital patient chart from the nineteenth until the twenty-first centuries, tentatively titled "Bedside Stories: Clinical Narrative and the Grounding of Modern Medicine" ("Narrative at the Bedside"). The cluster developed here is not concerned with the shifts in subject-positions between doctors and patients in medical training that Rita Charon calls an "aesthetic approach" (Narrative Medicine, 113).

20. See "Instructions for Authors: Case Reports": the editor presents case reports as "practice-based evidence"; Hacking, Historical Ontology, 180-81.

21. See Austin, "Performative Utterances" (The Norton Anthology of Theory, 1429).

22. Leder, Die Grenzgänge, 51-52.

23. During, Foucault and Literature, 17-18; 10.

24. Foucault, Discipline and Punish, 191.

25. See John Forrester, "If $p$, then what?" 12-13.

26. For medical case histories this body of scholarship includes: Hurwitz, "Form and Representation"; Kennedy, Revising the Clinic; Martus, ed. Fallgeschichten: von Dokumentation zu Fiktion (Case Histories: From Documentation to Fiction, Special Issue, Zeitschrift für Germanistik); Behrens and Zelle, eds., Der Ärtzliche Fallbericht; Süßmann, Scholz, and Engel, eds., Fallstudien; Düwell and Pethes, eds., Fall - Fallstudie Fallgeschichte; Pethes, "Vom Einzelfall zur Menschheit"; Vasset, ed., Medicine and Narration, 15-44.

27. Jägow and Steger, Literatur und Medizin, 231.

28. The distinction between these functions is based on the following article: Völkel, "Rezension," 108-09.

29. An adequate explanation of medical cases as "exemplars" can be found in W. B. Cannon's pedagogic "The Case Method of Teaching Systematic Medicine," published in the Boston Medical and Surgical Journal in 1900: "the intent of the proposed case system is, in short, to give the students printed data from actual histories," 33.

30. See Jolles, Einfache Formen (Simple Forms), 177-78.

\section{BIBLIOGRAPHY}

Der Ärtzliche Fallbericht Epistemische Grundlagen und textualle Strukturen dargestellter Beobachtung. Edited by Rudolf Behrens and Carsten Zelle. Wiesbaden: Harrossowitz Verlag, 2012.

Bakhtin, M. M. and P. M. Medvedev. The Formal Method in Literary Scholarship: A Critical Introduction to Sociological Poetics. Translated by Albert J. Wehrle. Baltimore, MD: Johns Hopkins University Press, 1978. 
Banks, Joanne Trautmann, and Anne Hunsaker Hawkins. "Editor's Column," Literature and Medicine 11, no. 1 (1992): vii-xi.

Bruno, Paul W. Kant's Concept of Genius: Its Origins and Function in the Third Critique. New York: Continuum, 2010.

Belling, Catherine. "Editor's Preface." Literature and Medicine 31, no. 1 (2013): vii-xii.

Cannon, W. B. "The Case Method of Teaching Systematic Medicine." Boston Medical and Surgical Journal 142, no. 2 (1900): 31-36.

Charon, Rita. Narrative Medicine: Honoring the Stories of Illness. Oxford: Oxford University Press, 2006.

Duff, David, ed. Modern Genre Theory. Harlow, Essex: Longman, 2000.

During, Simon. Foucault and Literature: Towards a Genealogy of Writing. New York: Routledge, 1992.

Düwell, Susanne, and Nicolas Pethes, ed. Fall - Fallstudie - Fallgeschichte: Zur Theorie und Geschichte einer Wissensform. Frankfurt: Campus, 2014.

Epstein, Julia. "Historiography, Diagnosis and Poetics." Literature and Medicine 11, no. 1 (1992): 23-44.

Forrester, John. "If $p$, then what? Thinking in Cases." History of Human Sciences 9, no. 1 (1996): 1-25.

Foucault, Michel. Archaeology of Knowledge. Translated by A. M. Sheridan Smith. London: Routledge, 1989.

. Discipline and Punish: The Birth of the Prison. Translated by Alan Sheridan. London: Penguin, 1991.

Fowler, Alastair. Kinds of Literature: An Introduction to the Theory of Genres and Modes. Oxford: Clarendon Press, 1992.

Frow, John. Genre. New York: Routledge, 2006.

Hacking, Ian. Introduction to The Structure of Scientific Revolutions by Thomas S. Kuhn. vii-xxxvii. Chicago: University of Chicago Press, 2012.

. Historical Ontology. Cambridge, MA: Harvard University Press, 2002.

Harpham, Geoffrey Galt. "Genre and the Institution of Research." PMLA 122, no. 5 (2007): 1635-643.

Hurwitz, Brian. "Form and Representation in Clinical Case Reports." Literature and Medicine 25, no. 2 (2006): 216-40.

"Instructions for Authors: Case Reports." Journal for Medical Case Reports, accessed December 27, 2013, http://www.jmedicalcasereports.com/authors/instructions/casereport.

Jägow, Bettina von, and Florian Steger. Literatur und Medizin: Ein Lexikon. Göttingen: Vandenhoeck and Ruprecht, 2005.

Jordanova, Ludmilla. "And?" British Journal for the History of Science 35, no. 3 (2002): 341-45.

Jolles, André. Einfache Formen: Legende, Sage, Mythe, Rätsel, Spruch, Kasus, Memorable, Märchen, Witz. Leipzig: Forschungsinstitut für neuere Philologie, 1930.

Kennedy, Meegan. Revising the Clinic: Vision and Representation in Victorian Medical Narrative and the Novel. Columbus, OH: Ohio State University Press, 2010.

Leder, Christoph Maria. Die Grenzgänge des Marcus Herz: Beruf, Haltung and Identität eines jüdischen Arztes gegen Ende des 18. Jahrunderts. Münster: Waxmann, 2007.

Lepenies, Wolf. Between Literature and Science: The Rise of Sociology [Die Drei Kulturen]. Translated by J. Hollingdale. Cambridge: Cambridge University Press, 1988. Original edition, Hanser, 1985.

Martus, Steffen, ed. Fallgeschichten (Case Histories: Special Issue). Zeitschrift für Germanistik 19 (2009).

Miller, Carolyn R. "Genre as Social Action." Quarterly Journal of Speech 70, no. 2 (1984): 151-67.

Moretti, Franco. Graphs, Maps, Trees: Abstract Models of Literary History. New York: Verso, 2005.

The Norton Anthology of Theory and Criticism. Edited by Vincent B. Leitch. New York: Norton, 2001. 
Pethes, Nicolas. "Vom Einzelfall zur Menschheit. Die Fallgeschichte als Medium des Wissenspopularisierung zwischen Recht, Medizin und Literatur." In Popularisierung und Popularität. Edited by G. Blaseio, H. Pompe and J. Ruchatz, 62-92. Cologne: DuMont-Literatur-und-Kunst-Verl, 2005.

Pomata, Gianna. "Sharing Cases: The Observationes in Early Modern Medicine." Early Science and Medicine 15 (2010): 193-236.

. "Observation Rising: Birth of an Epistemic Genre, 1500-1650." In Histories of Scientific Observation. Edited by Lorraine Daston and Elizabeth Lunbeck, 45-81. Chicago: Chicago University Press, 2011.

—. "Epistemic Genres: Popular and Learned Forms of Knowledge." In Wissenschaftsgeschichte und Gesichte des Wissens im Dialog: Connecting Science and Knowledge. Edited by Kaspar von Greyerz, Siliva Flubacher and Philipp Senn, 131-54. Göttingen: V\&R Unipress, 2013.

Reynolds, Mike. "Review: Modern Genre Theory, edited by David Duff." Language and Literature 10 (2001): 273-77.

Rousseau, George. "Literature and Medicine: The State of the Field." Isis 52 (1981): 406-24.

. "Medicine." In The Routledge Companion to Literature and Science. Edited by Bruce Clarke and Manuela Rossini, 169-80. New York: Routledge, 2011.

Ryan, Marie-Laure. "On the Why, What, and How of Generic Taxonomy." Poetics 10 (1981): 109-26.

Süßmann, J., S. Scholz, and G. Engel. Fallstudien: Theorie, Geschichte, Methode. Berlin: Trafo, 2007.

Todorov, Tzvetan. Genres in Discourse. Translated by Catherine Porter. New York: Cambridge University Press, 1990. Original edition 1978.

Turner, Henry S. "Lessons from Literature for the Historian of Science (and Vice Versa)." Isis 101 (2010): 578-89.

Vasset, Sophie, ed. Medicine and Narration in the Eighteenth Century. New York: Oxford University Press, 2013.

Völkel, Markus. "Rezension: Fallstudien: Theorie, Geschichte, Methode." Historische Zeitschrift 287 (2008): 108-09.

Voßkamp, Wilhelm. "Gattungen als Literarisch-Soziale Institutionen." In Textsortenlehre - Gattungsgeschichte. Edited by Walter Hinck, 27-44. Heidelberg: Quelle Meyer, 1977.

Warner, John Harley. "Narrative at the Bedside: The Transformation of the Patient Record in the Long Nineteenth Century." Paper presented at King's College London, Annual Lecture in the History of Healthcare and Medicine, London, UK, January 16, 2013. 